\title{
STUDIES IN THE BIOLOGY OF TALITRIDAE (CRUSTACEA, AMPHIPODA): EFFECTS OF ATMOSPHERIC HUMIDITY
}

\author{
By D. I. Williamson \\ Marine Biological Station, Port Erin
}

(Text-figs. I-9)

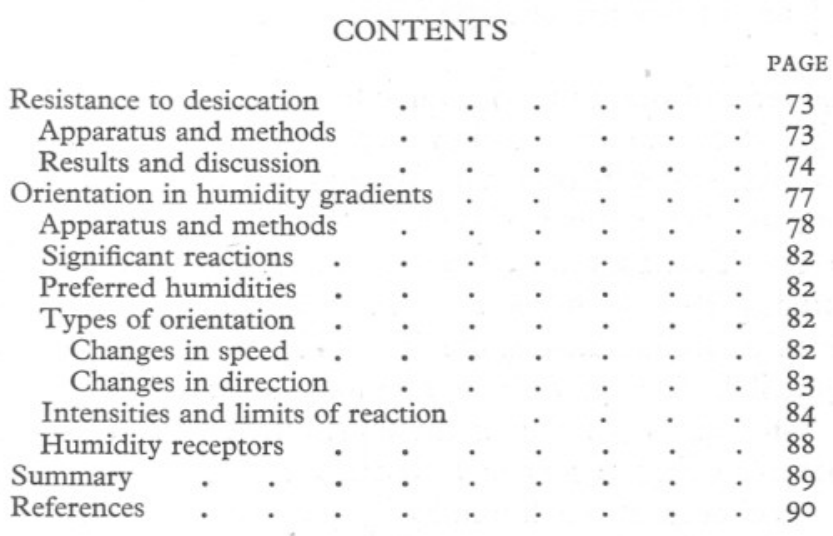

\section{Resistance to Desiccation}

Although the high-water Talitridae are normally terrestrial they show little structural modification compared with aquatic amphipods. They have no obvious adaptations to limit water-loss, and their branchial method of respiration is typically aquatic. It was to be expected, therefore, that the evaporating power of the air would play a considerable part in limiting their habitats and determining their habits. The following experiments were made to try and assess the importance of this factor.

\section{Apparatus and Methods}

A series of experiments was carried out to measure the survival times of Talitrus saltator (Montagu), Talorchestia deshayesii (Audouin) and Orchestia gammarella (Pallas) at different controlled humidities. Attempts were first made to control the humidity using saturated solutions of salts. The apparatus consisted of a glass dish, $18 \mathrm{~cm}$. diameter by $7 \mathrm{~cm}$. deep, divided horizontally by a copper-gauze platform of $0.25 \mathrm{~mm}$. mesh. Beneath the platform were three dishes of diameter $5 \mathrm{~cm}$. containing the solution; above it was an 'Edney' paper hygrometer. A Perspex lid, with central, corked hole for 
introducing animals, was sealed on to the dish with plasticine. When the air in the chamber reached equilibrium with the saturated solution, as shown by a steady hygrometer reading, animals were introduced. This, however, usually caused a considerable rise in the humidity. For example, at $15^{\circ} \mathrm{C}$. using saturated magnesium chloride solution, the hygrometer reading rose from the equilibrium value ( $58 \%$ ) to $70 \%$ R.H. in 15 min. on introducing three Talitrus and three Orchestia gammarella.

Besides showing the ineffectiveness of the method, this result shows the importance of the hygrometer as a humidity check, a precaution omitted by Backlund (1945) who measured the survival times of several animals, including O. gammarella. His apparatus gave a similar surface of saturated salt solution to mine, and he introduced ten specimens at a time. His results are considered later.

In the final form of the apparatus much more constant humidities were obtained by using sulphuric acid solutions in place of saturated salt solutions; the liquid surface was greatly increased by covering the whole floor of the chamber with solution, and the number of specimens in the apparatus was limited to six at a time (two of each species). The densities of the sulphuric acid solutions were measured with a hydrometer, and the equilibrium humidities were calculated from data contained in the International Critical Tables (National Research Council, U.S.A., I926). The experiments were carried out in a constant temperature room at $25^{\circ} \mathrm{C}$. Under these conditions the greatest variation in the hygrometer reading during any experiment was a rise of $5 \%$ R.H. after introducing specimens into a humidity of $36 \%$ R.H. At higher humidities introduction of specimens caused smaller rises in the hygrometer reading, and at $88 \%$ R.H. and above no rise could be detected.

Adult specimens of each species were transferred direct from laboratory stocks to the constant humidity apparatus, and survival time was measured from their introduction until no movement occurred, even when the animal was touched with a covered wire (insulated flex) through the hole in the lid.

\section{Results and Discussion}

In all three species the first noticeable effect of desiccation was a failure to co-ordinate the limb movements, and a tendency to fall on one side. Later there was a darkening of the extremities of the limbs and antennae, particularly in Orchestia. The survival times are shown in Table I. In saturated air all specimens were healthy after $24 \mathrm{hr}$. After $48 \mathrm{hr}$. those of Talorchestia deshayesii were dead, but the others were healthy. None of the species can withstand even small saturation deficiencies for more than a few hours, but Talitrus saltator always survives considerably longer than the others. This may be due to its greater size and consequent smaller surface:volume ratio, yet at all humidities the survival times of Talorchestia deshayesii and Orchestia gammarella are almost identical, in spite of the much greater size of the latter. 
It was found that in air of $36 \%$ R.H., in which adult specimens of Talorchestia deshayesii survived 75 min., juveniles of $T$. saltator and Orchestia gammarella of approximately the same size as an adult Talorchestia deshayesii both survived only $45 \mathrm{~min}$.

'If the relationship between rate of water loss.... and saturation deficiency is linear and survival is limited only by water loss, then the curve of longevity against saturation deficiency is hyperbola-shaped' (Johnson, I942). The linear relationship between saturation deficiency and the reciprocal of longevity (Fig. I) makes it reasonable to assume that, in the species under consideration,

Table I. Survival Times of Talitrus SALTATOR, ORChESTIA GAMMARELLA AND TALORCHESTIA DESHAYESII AT DIFFERENT Controlled Humidities. Temperature, $25^{\circ} \mathrm{C}$.

\begin{tabular}{|c|c|c|c|}
\hline \multirow{2}{*}{$\begin{array}{l}\text { Humidity } \\
\text { (R.H. \%) }\end{array}$} & \multicolumn{3}{|c|}{ Survival times (hr.) } \\
\hline & T. saltator & O. gammarella & T. deshayesil \\
\hline 100 & $\begin{array}{l}>48 \\
>48\end{array}$ & $\begin{array}{l}>48 \\
>48\end{array}$ & $\begin{array}{l}>24 \\
>24\end{array}$ \\
\hline 95 & $\begin{array}{l}16 \cdot 0 \\
14.5\end{array}$ & $\begin{array}{l}9 \cdot 0 \\
8 \cdot 0\end{array}$ & $\begin{array}{l}9 \cdot 0 \\
8 \cdot 0\end{array}$ \\
\hline 88 & $\begin{array}{l}7 \cdot 5 \\
7 \cdot 0\end{array}$ & $\begin{array}{l}5 \cdot 25 \\
4 \cdot 5\end{array}$ & $\begin{array}{l}4 \cdot 5 \\
3 \cdot 5\end{array}$ \\
\hline 75 & $\begin{array}{l}5 \cdot 0 \\
4 \cdot 75\end{array}$ & $\begin{array}{l}2.5 \\
2.5\end{array}$ & $\begin{array}{l}2.5 \\
2.5\end{array}$ \\
\hline 57 & $\begin{array}{l}2.5 \\
2.5\end{array}$ & $\begin{array}{l}\mathrm{I} \cdot 5 \\
\mathrm{I} \cdot 5\end{array}$ & $\begin{array}{l}I \cdot 5 \\
I \cdot 5\end{array}$ \\
\hline 36 & $\begin{array}{l}\mathrm{I} \cdot 75 \\
\mathrm{I} \cdot 5\end{array}$ & $\begin{array}{l}\mathrm{I} \cdot 5 \\
\mathrm{I} \cdot 0\end{array}$ & $\begin{array}{l}1 \cdot 25 \\
1 \cdot 25\end{array}$ \\
\hline
\end{tabular}

survival is limited only by water-loss, and that the rate of water-loss is not controlled by the animal. If this is the case, then the relationship between survival and saturation deficiency will be independent of the temperature, as has been shown to hold approximately true for several species of insect (Buxton, I932; Johnson, I942; Ludwig, I945). On this assumption it is possible to compare the survival times obtained by the writer for Orchestia gammarella with those given by Backlund (I945). At a supposed humidity of $86 \%$ at $20^{\circ} \mathrm{C}$. he obtained survivals of from 9 to $32 \mathrm{hr}$. This humidity corresponds to a saturation deficiency of $2.46 \mathrm{~mm}$. $\mathrm{Hg}$, under which conditions the survival time, from Fig. I, would be $5 \mathrm{hr}$. Similar discrepancies occur at both higher and lower humidities, Backlund always obtaining much the greater survival time. This must be attributed to the method of humidity control he employed, using saturated salt solutions, which, as mentioned earlier, I found to be quite ineffective.

The animals in the above experiments had no access to food, which is normally plentiful in the habitats of all three species. Similar experiments were therefore made in which food was available, to determine whether Talitridae can utilize water in their food, or produced by its oxidation, to 
counteract water-loss by evaporation. Dry foods, in the form of (I) biscuit, (2) dextrose and (3) dried Fucus frond, were left untouched by both Talitrus and Orchestia gammarella, so that the role of metabolic water could not be determined. With moist foods it was difficult to avoid raising the humidity in the chamber on introducing the food, but no rise in the hygrometer reading occurred in the following two cases:

I. At R.H. $=95 \%, T=\mathrm{I} 8^{\circ}$ C., a piece of Fucus serratus frond measuring $6 \times$ I cm. was provided as food. The wrack was dry to the touch, but flexible and not dried out. Three specimens of Orchestia gammarella were introduced. After $72 \mathrm{hr}$. one was dead, but the other two were healthy, and a considerable quantity of the wrack had been eaten.

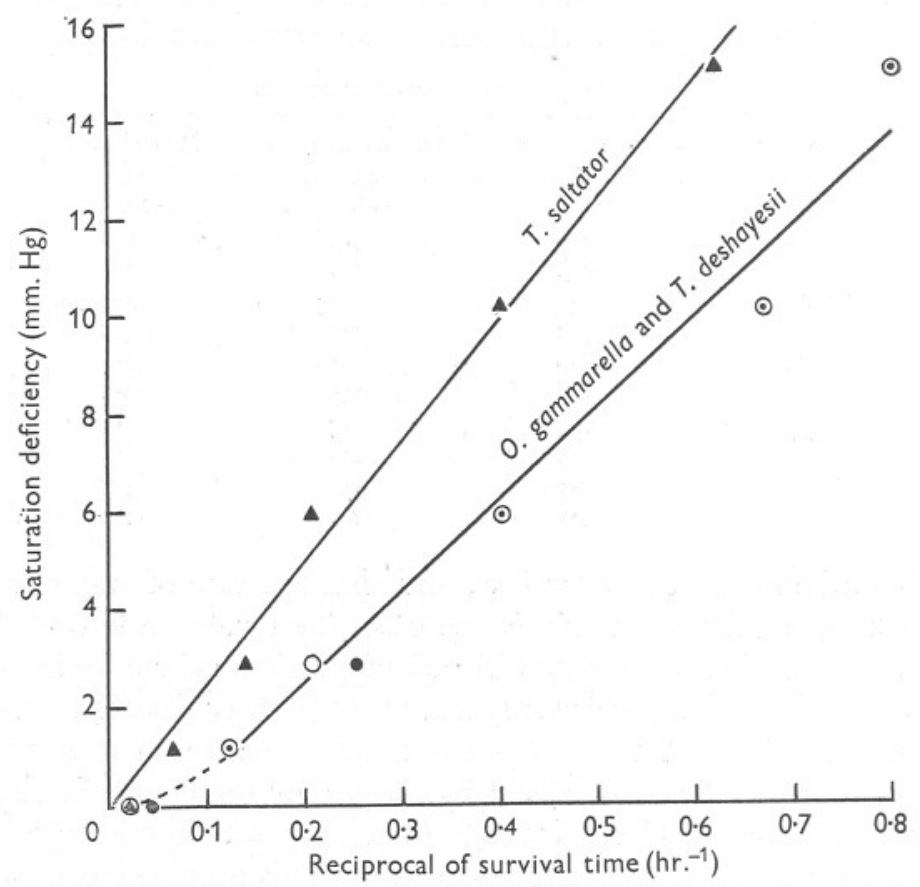

Fig. I. Reciprocal of mean survival time plotted against saturation deficiency.

$\boldsymbol{\Delta}$, Talitrus saltator; $\mathrm{O}$, Orchestia gammarella; $\bullet$, Talorchestia deshayesii.

II. At R.H. $=88 \%, T=25^{\circ}$ C., a I cm. cube of Drosophila medium (Darlington \& La Cour, 1942) was introduced into the chamber. Two normal specimens of Orchestia gammarella survived 20 and $22.5 \mathrm{hr}$. respectively. Two other specimens were introduced after first coating their mouthparts with paraffin wax to prevent them from feeding. One of these succeeded in removing the wax after $2 \mathrm{hr}$., and immediately began feeding. It was still healthy when the other died after $8 \mathrm{hr}$. All these specimens kept close to the food, usually touching it, and must have been in a local humidity appreciably higher than 
the general humidity of the chamber, the survival time of the waxed specimen being the same as that at $95 \%$ R.H. in the absence of food. Nevertheless, the greatly increased survival times of the specimens which fed suggests that water from food can play a very important part in enabling Talitridae to resist the effects of desiccation.

Field observations on the habitats and habits of the animals provide confirmation of the importance of food in this connexion. Backlund (I945) states that the humidity in the surface layers of wrack beds is at or near saturation only for a period of less than $4 \mathrm{hr}$. at night, and may fall well below $50 \%$ R.H. by day, and that the humidity of deep layers, though always high, is not always maximal. My own observations, made by immersing a paper hygrometer in different wrack beds for periods of over $30 \mathrm{~min}$., at depths of about I5 cm., have shown humidities from 85 to $90 \%$ R.H. These readings were always made when $O$. gammarella was present in the wrack in the vicinity of the hygrometer. The humidity of the normal habitat of $O$. gammarella is, therefore, such that in the absence of food the animal would die of desiccation in a few hours, and Talorchestia deshayesii, with similar resistance to desiccation, inhabits even drier situations. In another section of his work, Backlund comments on the great amounts of food consumed by Orchestia gammarella, 'but the amount of excrements is also great and most of the stuff eaten is not utilized'. I have noticed that talitrids always pass dry faeces, even when feeding on very moist food, suggesting that the amount of food eaten is determined by the animals' water requirements rather than their energy requirements.

O. gammarella is normally found among wrack on a non-sandy substratum, and Talorchestia deshayesii among, or under, wrack on a sandy substratum. Both species feed both by day and by night, and seldom wander far from the wrack, though they do come into the open more at night. A contrast is found in the behaviour of Talitrus, which feeds little by day but remains buried beneath the sand, often many yards away from the nearest wrack. At night it ranges over the beach from the lower slopes of sand dunes, well above highwater spring level, to mid-tide level or as low as the sea permits. These long periods without food by day and long migrations over the exposed beach at night probably could not be sustained by the other two species because of their much smaller resistance to desiccation.

\section{ORIENTATION IN HUMIDITy GRADIENTS}

As talitrids are very susceptible to desiccation even at high humidities, it seemed important to investigate their behaviour when a choice of humidities is available to them, to find to what extent, and by what means, they can distinguish between moist and dry air, and to compare the reactions of the different species. Experiments were made on the same three species for which the 
resistances to desiccation were compared, namely Talitrus saltator, Orchestia gammarella and Talorchestia deshayesii.

\section{Apparatus and Methods}

To produce humidity gradients, a form of Gunn \& Kennedy's 'alternative' chamber was used (Gunn \& Kennedy, I936). The apparatus measured I8 cm. diameter by $7 \mathrm{~cm}$. deep, and the platform was of copper gauze of $0.25 \mathrm{~mm}$. mesh. Resting on the platform were two 'Edney' paper hygrometers, one on either side of the chamber, with the sensitive paper in each case to the outside, and the edge of each instrument $\mathrm{I} \mathrm{cm}$. from the edge of the chamber to allow a clear path for the animals round the perimeter.

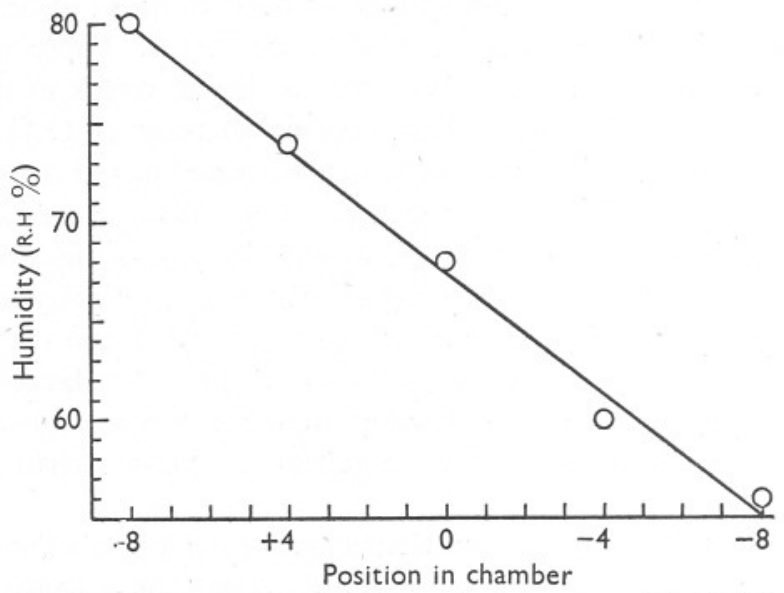

Fig. 2. Typical humidity gradient in 'alternative' chamber. Humidities at $\mathrm{I} \mathrm{cm}$. from edge of chamber. Temperature, $15^{\circ} \mathrm{C}$.

The calibration of the hygrometers was checked at intervals of about a month over sulphuric acid solutions of measured density, and they were checked against each other at air humidity every few days so that any variation in the calibration of either instrument would have been detected. The calibration never varied by more than $2 \%$ R.H. in any month.

In the majority of cases the dishes beneath the platform contained sulphuric acid solutions of different strengths, but caustic soda and caustic potash, both solid and solution, and solid calcium chloride were used in several of the experiments with similar results to those obtained with sulphuric acid at similar humidities, showing that the animals were reacting to the humidity gradient and not to any property of the desiccating agent.

By placing the desiccating agent in two well-separated dishes an approximately linear gradient of humidity was obtained. A typical gradient is shown in Fig. 2. If each half of the floor of the chamber is covered with dishes, meeting at the boundary of the moist and dry halves, a much steeper gradient 
is obtained in the boundary region, with a very gradual gradient on either side (such an arrangement was used by Gunn (1937), who includes an S-shaped graph of a typical gradient under these conditions). While animals are likely to give a more obvious response to the steep gradient, the nature of the response is likely to be seen more clearly in a linear gradient where reactions will not be confined to the boundary region.

The platform was marked with a diameter, dividing the chamber into moist and dry halves, and with lines parallel to this diameter at $2 \mathrm{~cm}$. intervals. With the aid of these lines the distances of animals from the diameter could easily be estimated to the nearest centimetre, such distances in the moist half being regarded as positive and in the dry half as negative, so that the position of an animal could be referred to by a number between +9 and -9 .

$\mathrm{Up}$ to $3 \mathrm{hr}$. was required for equilibrium to become established in the chamber. Specimens were not introduced until the hygrometers had been showing steady readings for at least half an hour. Only one specimen was introduced into the chamber at one time, and numerical values of the intensity of reaction to the gradient were based on the respective times spent by the animal in each half of the apparatus. In most of the previous work on the behaviour of animals in humidity gradients using an 'alternative' chamber, several specimens have been introduced at once, and measures of intensity of reaction based on readings of the number of animals in each half (Gunn, I937; Gunn \& Cosway, I938; Pielou \& Gunn, I940; Lees, 1943). This method gives greater uniformity of results, since each result is an average for several specimens, but it cannot be applied to Talitridae because of their high rate of waterloss. Not only does the introduction of several talitrids noticeably affect the humidities in the chamber, but, particularly at low humidities, the steepest gradients leading to the moistest air surround the animals themselves. It was found in several preliminary experiments using five to ten specimens of Orchestia gammarella that all the specimens soon formed an aggregation round any stationary individual irrespective of its position in the chamber.

Young specimens of all species jump much more frequently than do adults, making it very difficult to plot their positions accurately. For this reason specimens below a size roughly corresponding to that of sexual maturity were avoided $(9 \mathrm{~mm}$. for Talitrus, $8 \mathrm{~mm}$. for Orchestia gammarella and $6 \mathrm{~mm}$. for Talorchestia deshayesii, all lengths with abdomen flexed). Apart from this no conscious selection was made.

The apparatus was always illuminated from directly above, and, to allow for any visual orientation of the specimen to external objects, the chamber was turned through $180^{\circ}$ half way through each set of observations. On first introducing specimens, they would frequently feign death for periods of over a minute or show unusually great activity with much jumping. To allow them to become acclimatized to their surroundings no observations were recorded for the first $5 \mathrm{~min}$. after introduction. 
Position records (Figs. 3-6) were obtained by noting the displacement of the animal from the diameter at $15 \mathrm{sec}$. intervals (shown by open circles on the graphs), and positions of additional turning points were also recorded (shown by black circles).

As a measure of the intensity of reaction to the humidity gradient the "excess percentage time' was used, i.e.

$$
\frac{\text { (time spent in moist half) }- \text { (time spent in dry half) }}{\text { (time spent in moist half })+(\text { time spent in dry half })} \times 100 \text {, }
$$

which gives a theoretical range of values from $+100 \%$, representing an animal which does not leave the moist half, to $-100 \%$, representing an animal which
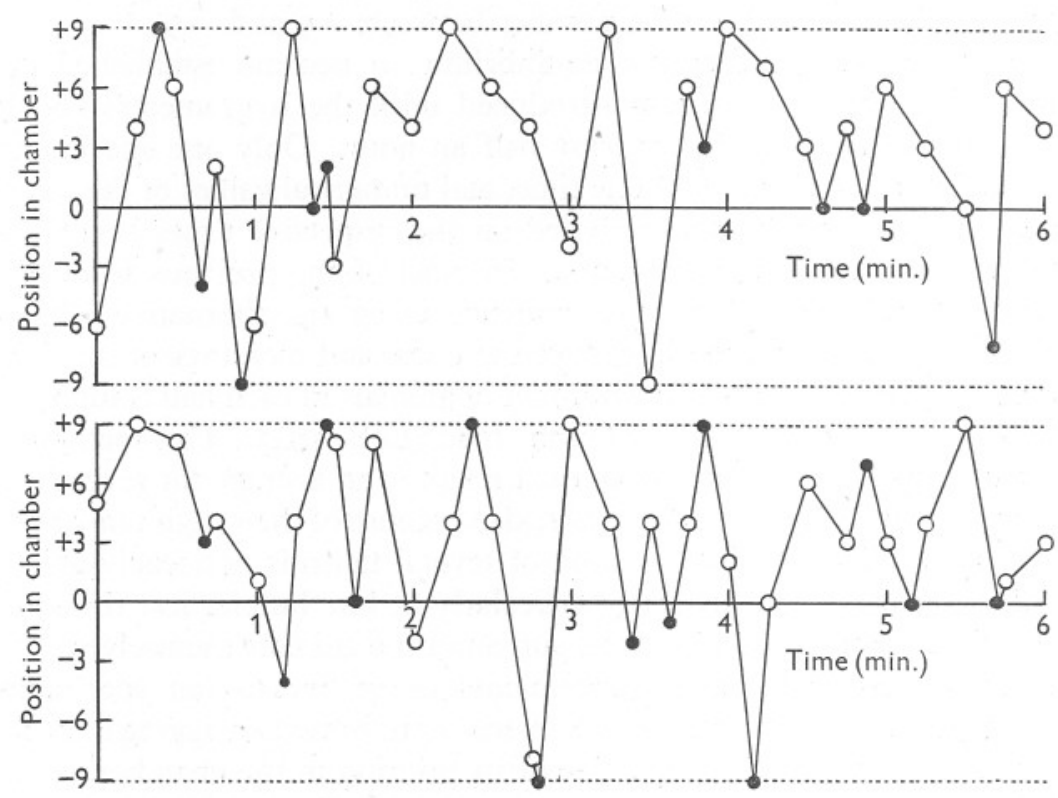

Fig. 3. Position record of Talitrus saltator in humidity gradient $92-38 \%$ R.H. at $16^{\circ} \mathrm{C}$. The apparatus was turned through $180^{\circ}$ between the upper and lower records. $\bigcirc$, positions at I5 sec. intervals; , positions of additional turning points.

does not leave the dry half, with $\circ \%$ representing no preference. Intensities were normally calculated from observations over two periods of $8 \mathrm{~min}$. each, the apparatus being turned round between the two periods. With a few, large, fast-moving specimens of Talitrus, observations were confined to two periods of 5 min. each, while with a few slow-moving specimens of Talorchestia deshayesii, observations were continued for Io or even $12 \mathrm{~min}$. in each period. In all cases the average time for one complete circuit of the chamber was less than $3 \%$ of the total time for which observations were recorded. Intensities of reaction were calculated either from position records or, more usually, from observations on the times when the specimen crossed from one half to the other. 


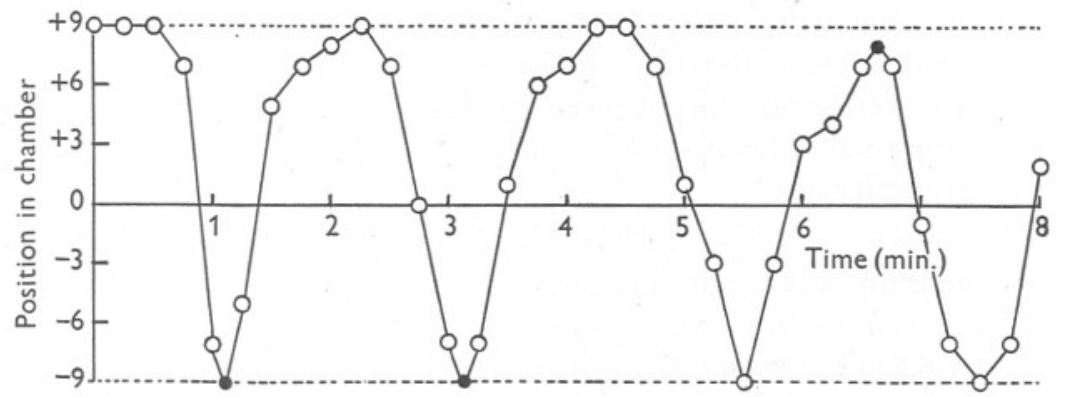

[Fig. 4. Position record of Orchestia gammarella in humidity gradient $86-66 \%$ R.H. at $\mathrm{I} 5^{\circ} \mathrm{C}$.

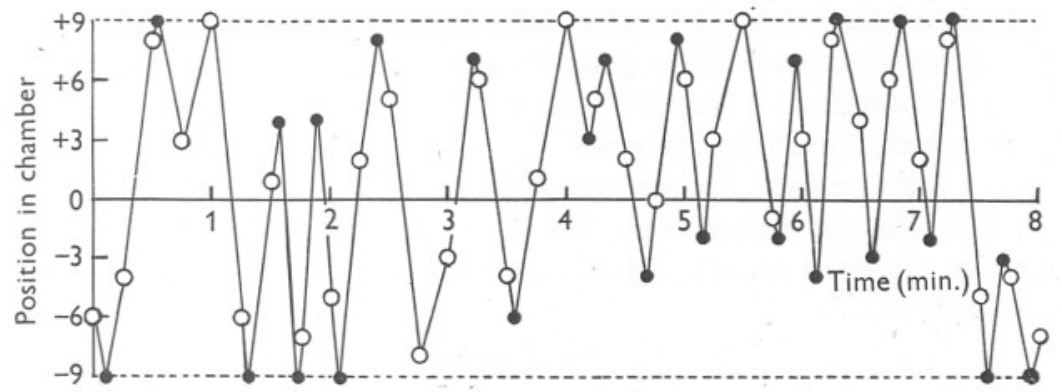

Fig. 5. Position record of Orchestia gammarella in humidity gradient $76-50 \%$ R.H. at $16^{\circ} \mathrm{C}$.

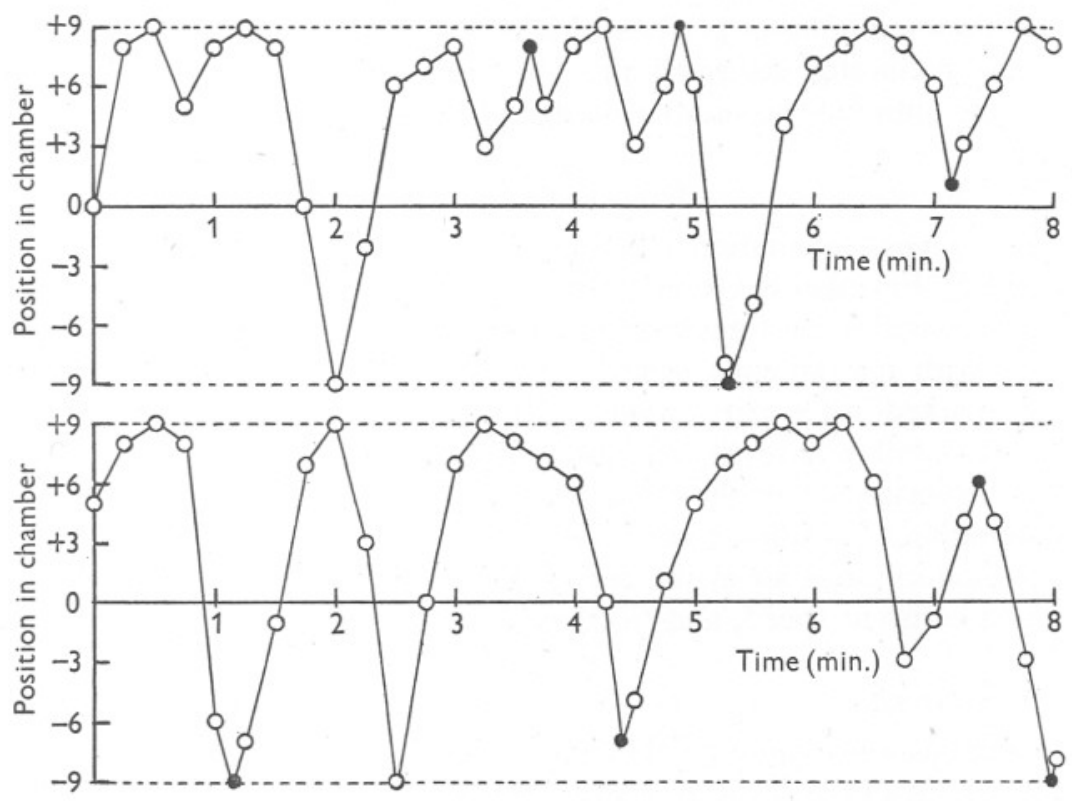

Fig. 6. Position record of Talitrus deshayesii in humidity gradient $96-78 \%$ R.H. at $\mathrm{I} 5^{\circ} \mathrm{C}$. The apparatus was turned through $180^{\circ}$ between the upper and lower records. JOURN. MAR. BIOL. ASSOc. vol. xxx, I95I 
All experiments were made at temperatures between $14^{\circ}$ and $16.5^{\circ} \mathrm{C}$.

Control experiments, in which the humidity was the same on both sides of the chamber, were made for all three species. Intensities of reaction greater than twice the standard deviation in control experiments for each species were regarded as significant.

\section{Significant Reactions}

The minimum significant intensities for Talitrus saltator, Orchestia gammarella and Talorchestia deshayesii are, respectively, I3, 5 and I5. The low figure for Orchestia gammarella, compared with the other two species, is the result of its stronger thigmo-taxis. While in control experiments this species almost invariably followed a single track round the perimeter of the chamber, the other two occasionally left the sides and wandered over the platform. The theoretical maximum deviation from zero intensity of an animal which moves round the perimeter at a uniform rate without turning is the percentage time taken for one circuit of the chamber. This value for an average O. gammarella over two $8 \mathrm{~min}$. periods is estimated at about $3 \%$, and this value was seldom exceeded in control experiments for the species. The less restricted paths followed by Talitrus saltator and Talorchestia deshayesii resulted in greater variation in controls.

\section{Preferred Humidities}

In over 250 experiments on the three species, at humidities from 25 to $100 \%$ R.H., all the significant reactions were positive. This means that whenever talitrids show a humidity preference it is for the highest humidity available, up to, and including, saturated air. The preferred humidity is therefore the same as the optimum humidity as judged by survival times.

\section{Types of Orientation}

In this paper, orientation reactions are named according to the system described by Fraenkel \& Gunn (I940).

All three species are thigmo-tactic, and tend to keep to the outside of the chamber with one antenna against the glass wall. This behaviour is most strongly marked in Orchestia gammarella which seldom leaves the outer wall, and therefore follows a restricted course. The other two species more frequently forsake the perimeter for the open platform.

Examination of position records (Figs. 3-6) shows that talitrids spend most of their time in moist air as the result of two factors: (i) the animals do not move at a constant speed, and (ii) they do not move in a constant direction.

\section{Changes in Speed}

The animals move more quickly in dry than in moist air. This is shown, to some extent, in all the position records, but Fig. 4 shows a specimen of O.gammarella whose hygro-positive reaction results entirely from this type of orienta- 
tion. Movement at a constant speed round the perimeter of the chamber would give a sinusoidal graph, but the differential velocity of the specimen results in broad peaks and narrow, more pointed troughs. This orientation is an example of 'low hygro-ortho-kinesis' (Fraenkel \& Gunn, 1940).

(It is probable that the stimulus in the case of talitrids and several other species which react to differences of humidity is not humidity but rate of water-loss. The conventional practice of describing such orientations in terms of humidity is followed here, but to describe them in terms of evaporation would be more correct.)

Two variants of hygro-ortho-kinesis are sometimes shown by talitrids:

(a) When the highest humidity in the chamber exceeds about $90 \%$ R.H., animals will frequently stop in the more humid regions and remain motionless for up to $30 \mathrm{sec}$. Halts in the drier regions are extremely rare and seldom exceed $5 \mathrm{sec}$. This reaction is shown by all three species, but is most common in O. gammarella.

(b) At lower humidities (less than about 50\% R.H.) the animal may start jumping and will continue jumping until it lands in moister air, when walking is resumed. The jumping is quite random in direction, but usually three or four jumps are sufficient to take the animal out of the drier region. Though this reaction has been seen in all three species, it is most common in Talorchestia deshayesii and least common in Talitrus saltator.

Variant $a$ is an extreme case of variation in the velocity of locomotion, while $b$ involves variations not only in velocity but also in the type of locomotion. Both are examples of greater locomotor activity in drier air or low hygro-ortho-kinesis.

\section{Changes in Direction}

In Fig. 3, 5 and 6 turning reactions play a very important part in the hygropositive behaviour of the specimens; they turn more frequently when moving from moist to dry air than when moving from dry to moist air. Turns are not always made towards moister or away from drier air, in fact, in some cases, turns towards drier air are almost as frequent as those towards moister air (e.g. Fig. 5). The hygro-positive reaction results from the intervals between turns tending to be relatively shorter when the animal is moving into drier air, or, as Ullyott (I936) found with flatworms in a gradient of light intensity, 'an increase in stimulating intensity produces an increase in the rate of change of direction'.

As the animals usually follow the outer wall of the chamber, turns are usually complete reversals of direction, and the direction of locomotion is not truly random. The restrictions in the direction of locomotion are, however, not imposed by the humidity, but by the tendency of the animals to keep close to projecting objects (thigmo-taxis). As far as the humidity gradient is concerned the direction of locomotion is random. This is seen more clearly when speci- 
mens temporarily leave the outer wall of the chamber-behaviour only very occasionally seen in Orchestia gammarella, but more common in Talitrus saltator and Talorchestia deshayesii. On the open platform the undirected nature of the turning reaction is very obvious. It does not result (except by chance) in motion towards or away from the source of the stimulus (evaporation), and is not governed by the direction of the humidity gradient, but by comparisons of the intensity of the stimulus at successive times. By a 'process of alternate stimulation and adaption the animal is gradually brought to the weaker end of the gradient' (Ullyott, I936). The orientation is clearly of the same type as that shown by Dendrocoelum in a gradient of light intensity, described by Ullyott under 'phobotaxis', and later re-named 'klino-kinesis' by Fraenkel \& Gunn (1940).

In very steep humidity gradients talitrids will occasionally stop when moving into dry air, then move backwards for about $\mathrm{I} \mathrm{cm}$. before turning. Comparable behaviour is common in Paramecium when moving into unfavourable conditions, and has been included under klino-kinesis by Gunn \& Walshe (I94I). A similar type of reaction is frequently shown by wireworms in steep gradients of humidity, but was regarded by Lees (I943) as a directed reaction, and therefore described as 'klino-taxis'. However, his own figures show that neither the direction of recoil nor the direction of the track after turning bore any relation to the direction of the gradient, the direction of recoil being determined solely by the original path of the wireworm, and the new path frequently leading the animal back into dry air almost immediately.

True klino-kinesis as a reaction to humidity gradients is shown by the beetle, Tenebrio molitor, which shows a preference for dry air (Pielou \& Gunn, I940). The orientation involves 'trial movements with the antennae...followed by a fairly precise movement towards the dry side'. Nothing comparable with this type of reaction appears to occur in wireworms or talitrids whose turning reactions in humidity gradients are properly described as 'klino-kinesis'.

Normally talitrids orientate in humidity gradients by a combination of ortho-kinesis and klino-kinesis, though weaker reactions may consist solely of ortho-kinesis (as in Fig. 4). The relative importance of the two types of reaction varies considerably between different individuals in the same gradient, but no consistent differences in this respect were noticed between different species or between different sizes or sexes of the same species.

\section{Intensities and Limits of Reaction}

The intensities of reaction of similar specimens of the same species in the same humidity gradient often differ enormously; for example, with a gradient 98-7I \% R.H. at I $5^{\circ}$ C. three different specimens of Orchestia gammarella gave intensities of $\mathrm{I} 7,30$ and $74 \%$ excess time. These individual differences do not appear to be correlated with size, sex or previous desiccation. In spite of this lack of uniformity in the intensities of reaction of different individuals, there 
is consistency in the reaction of different specimens of the same species; for if one specimen is found to react to a certain gradient then, in general, all other specimens of the species will react to the same gradient, and if no reaction is given by one specimen then all other specimens will fail to react. This makes it possible to make quite a sharp distinction between those humidity gradients to which members of each species will react and those to which they will not.

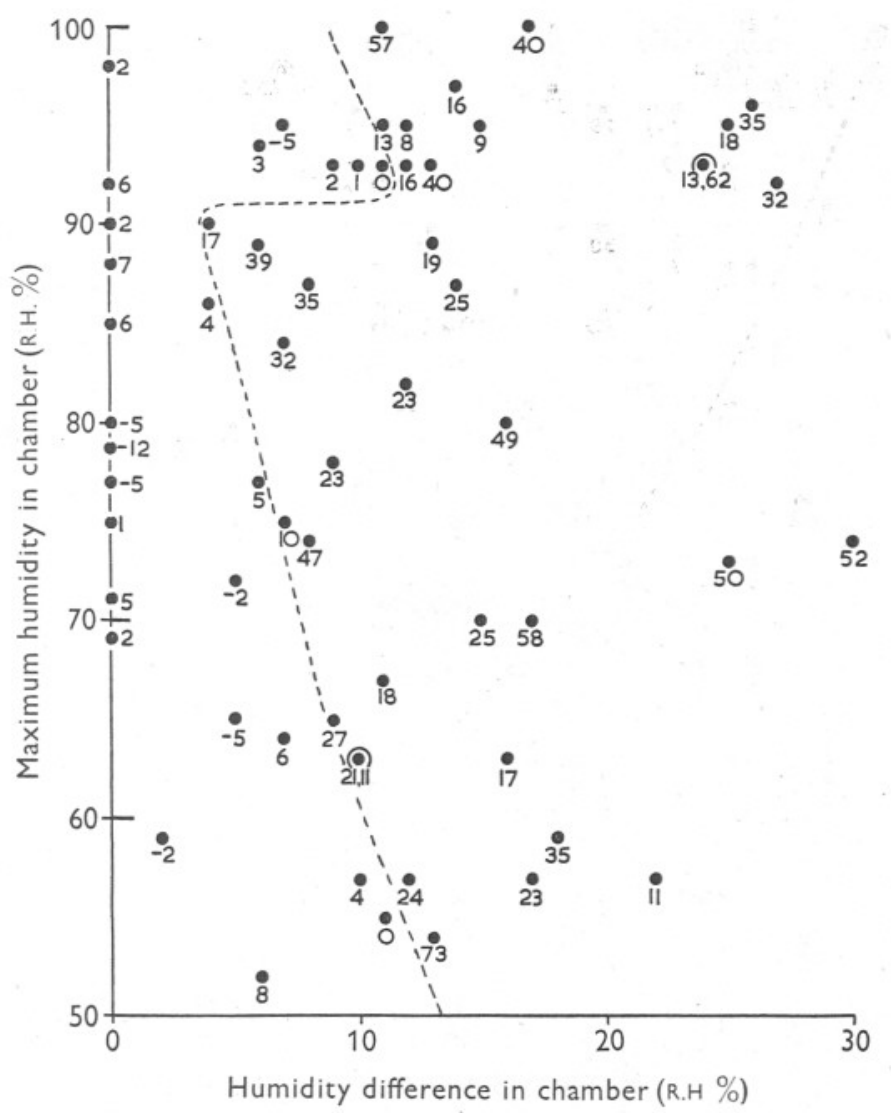

Fig. 7. Intensities and limits of reaction of Talitrus saltator to humidity gradients in 'alternative' chamber. Figures beside points give intensities of reaction. Circles around points denote that two or more experiments have been made using the same humidity gradient. The broken line marks the approximate limit of significant reaction. Temperature, I4 $4-16 \cdot 5^{\circ} \mathrm{C}$.

This is done in Figs. 7-9. The free-hand dotted line in each case divides those gradients to which the vast majority of reactions were significant (on the right) from those to which the vast majority were not significant (on the left). (The limits of significance for each species are given, and differences in their value are discussed, earlier.) 
The minimum humidity difference required to give a significant reaction varies at different parts of the humidity range, and the manner in which it varies differs with the species. Thus Talitrus saltator gives a significant reaction to a humidity difference of $4 \%$ R.H. when the highest humidity in the chamber is $90 \%$, but humidity differences of over 10 \% R.H. are required to obtain a reaction when the maximum humidity is above $92 \%$ or below $60 \%$ R.H.

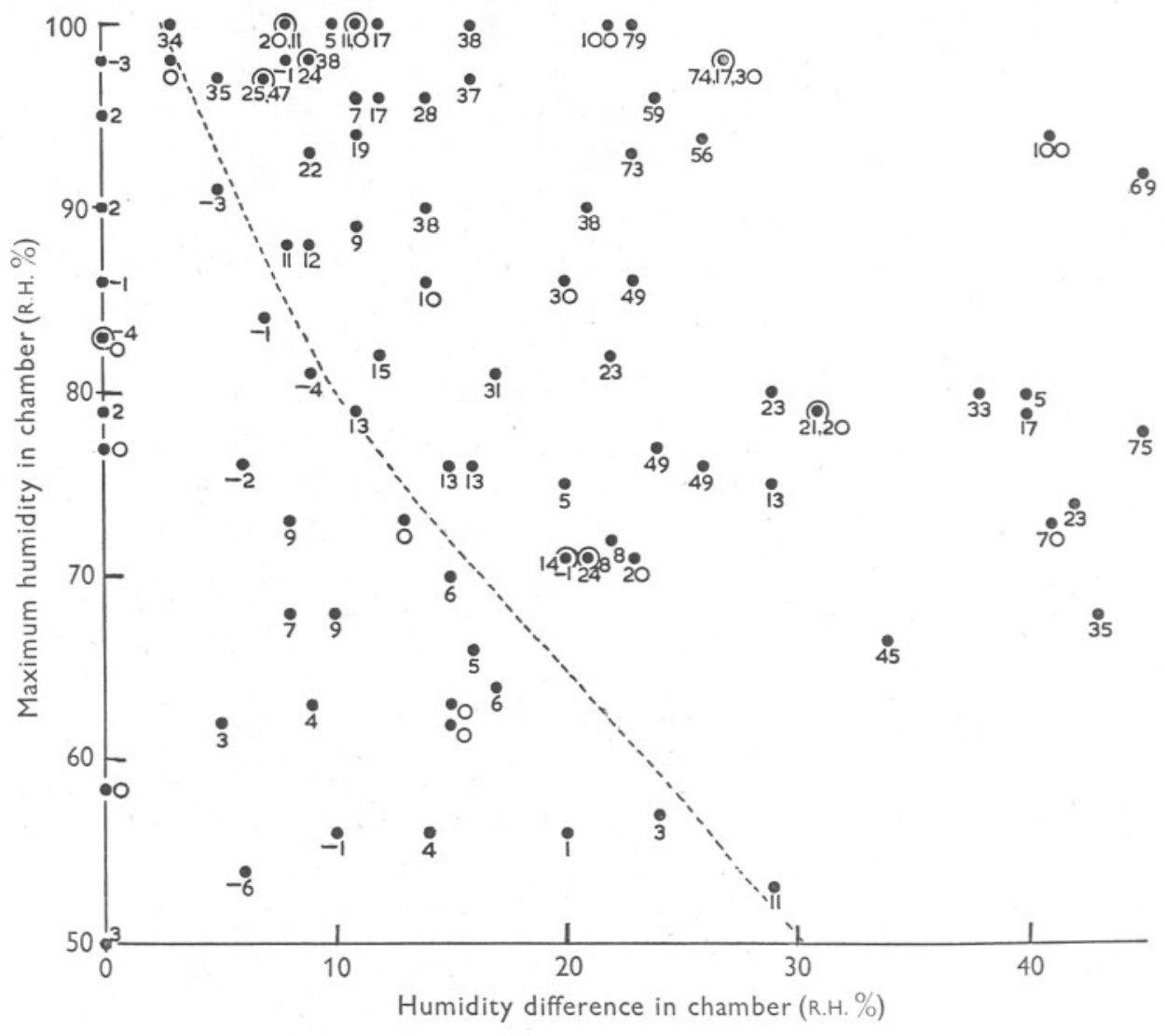

Fig. 8. Intensities and limits of reaction of Orchestia gammarella to humidity gradients in 'alternative' chamber. Temperature, I4-I6. $5^{\circ} \mathrm{C}$. For further explanation see Fig. 7.

(Fig. 7). Orchestia gammarella is most sensitive to small humidity differences when the maximum humidity is $100 \%$ R.H., when it shows a significant reaction to a humidity difference of $3 \%$ R.H., but its sensitivity decreases steadily with decreasing humidity (Fig. 8). Talorchestia deshayesii reacts to a $5 \%$ R.H. difference when the maximum humidity is between 60 and $65 \%$ R.H., but its sensitivity decreases rapidly at lower, and more gradually at higher, humidities (Fig. 9). 
In all three species there is no uniform increase in intensity of reaction with increasing humidity gradient, either considering results over the whole humidity range or any section of it. This might be attributed to the large individual differences mentioned earlier, but corresponding values for Porcellio (Gunn, 1937) show the same feature in spite of the averaging effect of using several (five) specimens in each gradient. Values for Agriotes, on the other hand, increase steadily with increases in both the humidity gradient and the maximum humidity (Lees, I943).

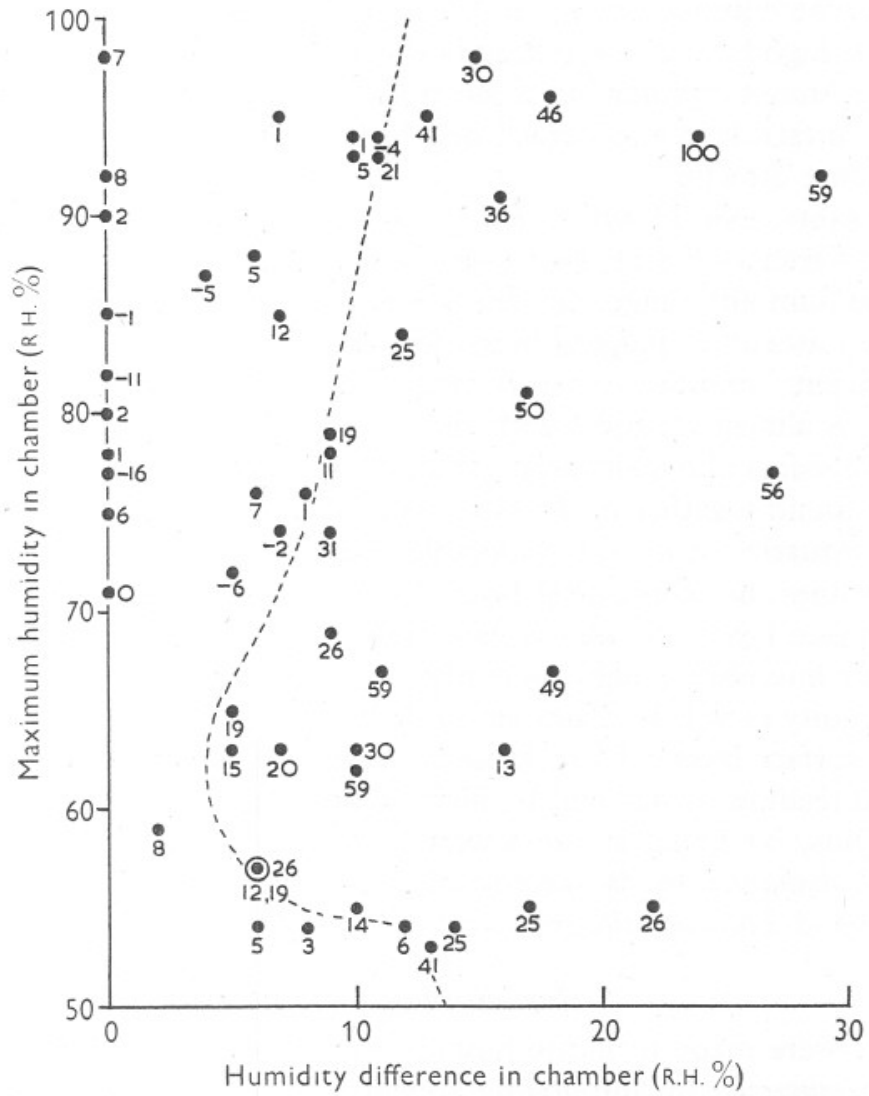

Fig. 9. Intensities and limits of reaction of Talitrus deshayesii to humidity gradients in 'alternative' chamber. Temperature, $14-16 \cdot 5^{\circ} \mathrm{C}$. For further explanation see Fig. 7.

Specific differences among talitrids in the humidity zone in which they are most sensitive can be related to their field behaviour to a considerable degree. Talitrus saltator is unable to distinguish between different humidities above $92 \%$ R.H. This figure probably represents the lowest humidity at which it can safely spend its day-time, non-feeding period, and it seems significant that its greatest sensitivity should be shown at humidities just below this value. It is 
probable, as mentioned earlier, that the humidity reaction of talitrids depends on their ability to compare different rates of water-loss, which is governed by saturation deficiency. A relative humidity of $92 \%$ at $15^{\circ} \mathrm{C}$. corresponds to a saturation deficiency of $\mathrm{I} .02 \mathrm{~mm}$. $\mathrm{Hg}$, under which conditions (from Fig. I) an adult Talitrus would survive over $20 \mathrm{hr}$. It is therefore suggested that Talitrus may use its humidity sense in determining the depth of its burrow, but the humidity in the burrow is not known.

Orchestia gammarella is the only species which inhabits the deeper layers of wrack beds where humidities are at or near saturation, and it may use its great sensitivity at high humidities to keep in this environment. To quote Backlund (I945), 'the humidity gradation is steep in the border horizon between deep layers and surface layers [of wrack beds]. Here many animals can use their humidity sense directly'.

The humidity zone in which Talorchestia deshayesii reacts to the smallest humidity differences lies at what must be the extreme lower limit of its environmental humidity range, but this species frequently lives in this humidity zone where mistakes in judging humidities might soon lead to desiccation, so that an efficient humidity sense is vital. The resistance of $T$. deshayesii to desiccation is almost identical with that of Orchestia gammarella, yet Talorchestia deshayesii is almost invariably found in drier situations. When the two species are found together in the same wrack bed, as frequently occurs at the mouths of estuaries, it is very noticeable that in dry weather Orchestia gammarella occupies the moist, deep layers, while Talorchestia deshayesii inhabits the dry, surface layers. Orchestia gammarella invades the surface layers only when the air humidity is high, as at night.

The humidity in wrack strings on sandy beaches is probably very similar to that in the surface layers of wrack banks. Here, too, Talorchestia deshayesii is to be found feeding by day and by night, but at night it is joined by Talitrus saltator. Thus, by living at the lowest humidities at which it can survive, Talorchestia deshayesii by day avoids competition for food with both Orchestia gammarella and Talitrus saltator.

\section{Humidity Receptors}

Attempts were made to locate humidity receptors in Talitrus saltator and Orchestia gammarella by amputating appendages or insulating different parts of the body from the atmosphere with wax or vaseline, and observing such specimens in humidity gradients. Specimens treated in the following ways were observed in a gradient of $95-70 \%$ R.H.: (i) Talitrus saltator with antennae amputated; (ii) Orchestia gammarella with antennules and antennae covered with vaseline; (iii) Talitrus saltator with head, mouthparts, antennules and antennae covered with wax; (iv) Orchestia gammarella with dorsal surface covered with wax; and (v) Talitrus saltator with dorsal surface and thoracic legs covered with vaseline. 
All these animals showed well-marked preferences for moist air, orientating in the same manner as untreated specimens. Attempts were also made to cover the under surfaces of the animals with wax, vaseline or cellulose paint, but in all cases the specimen was either killed or completely immobilized. No doubt the covering of the branchiae had a pathological effect.

Gunn (1937) showed that covering the antennae of Porcellio with vaseline did not affect its humidity reactions, and suggested that receptors might be present on the thorax. Lees (I943) showed by amputation that in wireworms the antennae, labial palps and maxillary palps were all concerned in humidity reception, but he found no specific organs of reception. This, together with the discovery that the animals reacted to differences in saturation deficiency rather than relative humidity, led him to suggest that the reaction was initiated by loss of water from the head appendages, and in particular from the unsclerotized, intersegmental regions. These two animals are the only normally hygro-positive species which have been investigated previously for humidity receptors, and in neither case has any receiving organ been found. In view of this, and because I have been unable to locate the site of humidity reception in talitrids, I suggest that their reactions to humidity are brought about by evaporation from the whole body surface, and particularly from the thin-walled branchiae which probably lose water more rapidly than the rest of the body.

Organs of humidity reception have been located and identified in the hygronegative Tenebrio (Pielou \& Gunn, I940), and Pediculus (Wigglesworth, I94I). In both cases they are situated on the antennae. It has also been suggested that certain of the antennal hairs of mosquitoes are hygro-sensitive (Thomson, I938). In all these cases the organs are thought to act like hygrometers, and in the case of the mosquito it has been shown that the intensity of the humidity reaction depends on the gradient of relative humidity and not on differences in saturation deficiency. Animals which react to humidity differences appear, therefore, to fall into two distinct classes: (a) those with hygrometer-like receptors, which react to differences in relative humidity, and $(b)$ those with no specific receptors, which react to differences in rates of evaporation. The Talitridae fall in the second category.

This work was carried out at King's College, Newcastle-upon-Tyne, under the supervision of Prof. A. D. Hobson, whom I wish to thank for advice and encouragement.

\section{SUMMARY}

The survival times of Talitrus saltator, Orchestia gammarella and Talorchestia deshayesii were measured at different controlled humidities.

All are very susceptible to desiccation, but Talitrus saltator survives much longer than either of the other species in unsaturated air in the absence of food.

Survival times are greatly increased if moist food is available. 
In humidity gradients all species select moist air, orientating by means of an ortho-kinesis and a klino-kinesis.

At $15^{\circ} \mathrm{C}$., $T$. saltator reacts to the smallest gradients when the maximum humidity is $92 \%$ R.H., but is unable to distinguish between different humidities above this figure. Orchestia gammarella and Talorchestia deshayesii react to the smallest gradients when the maximum humidities are Ioo and $62 \%$ respectively.

Attempts to locate humidity receptors were unsuccessful. The animals are thought to react to rate of water-loss from the whole body.

\section{REFERENCES}

BACKLund, H. O., 1945. Wrack Fauna of Sweden and Finland. Ecology and chorology. Opuscula Entomologica Suppl. 5. 236 pp. Lund.

Buxton, P. A., I932. Terrestrial insects and the humidity of the environment. Biol. Rev., Vol. viI, pp. 275-320.

Darlington, C. D. \& La Cour, L. F., 1942. The Handling of Chromosomes. I65 pp. London.

Fraenkel, G. S. \& GunN, D. L., I940. The Orientation of Animals. 352 pp. Oxford.

GunN, D. L., 1937. The humidity reactions of the wood-louse Porcellio scaber (Latreille). fourn. Exp. Biol., Vol. I4, pp. 178-86.

GunN, D. L. \& Cosway, C. A., I938. The temperature and humidity reactions of the cockroach. V. Humidity preference. Fourn. Exp. Biol., Vol. 15, pp. 555-63.

GunN, D. L. \& KenNedy, J. S., I936. Apparatus for investigating the reactions of land arthropods to humidity. Fourn. Exp. Biol., Vol. I3, pp. 450-9.

Gunn, D. L. \& Walshe, B. M., I94I. Klino-kinesis in Paramecium. Nature, Vol. I48, p. 564 .

Johnson, C. G., I942. Insect survival in relation to water-loss. Biol. Rev., Vol. 17, pp. I5I-77.

LeEs, A. D., 1943. On the behaviour of wireworms of the genus Agriotes Esch. (Coleoptera, Elateridae). I. Reactions to humidity. Fourn. Exp. Biol., Vol. 20, pp. 43-53.

Ludwig, D., I945. The effects of atmospheric humidity on animal life. Physiol. Zool., Vol. 18, pp. 103-35.

National Research Council, U.S.A., 1926. International Critical Tables of Numerical Data, Physics, Chemistry and Technology. New York.

Pielou, D. P. \& GunN, D. L., I940. The humidity behaviour of the mealworm beetle, Tenebrio molitor L. Parts I, II and III. Fourn. Exp. Biol., Vol. I7, pp. 286-94, 295-306, 307-16.

Thomson, R. C. M., 1938. The reactions of the mosquito to temperature and humidity. Bull. Ent. Res., Vol. 29, pp. I25-40.

Ullyott, P., I936. The behaviour of Dendrocoelum lacteum. II. Responses in nondirectional gradients. Fourn. Exp. Biol. Vol. 13, pp. 265-78.

Wigglesworth, V. B., I94I. The sensory physiology of the human louse Pediculus humanus corporis De Geer (Anopleura). Parasitol., Vol. 33, pp. 67-I09. 